\title{
This is My Country (?) \\ Exploring Denial in Relation to the Negative Aspects of Nationalism in Indonesia.
}

\author{
Edward Salim ${ }^{1}$, Liem Satya Limanta ${ }^{2}$ \\ English Department, Faculty of Language and Literarture, Petra Christian University, Siwalankerto 121- \\ 131, Surabaya 60236, Indonesia. \\ E-mail: Edalius12@gmail.com ${ }^{1}$, satya @ petra.ac.id ${ }^{2}$
}

\begin{abstract}
Nationalism is a central part of Indonesian ideology, but few Indonesians recognise or acknowledge its more negative elements out of denial. As such, the nation rarely addresses the numerous human right violations committed in the past for the sake of upholding this ideology. In response to this issue, I wrote this novel to show the detrimental effects of denial have on people, as well as the way to cope with it. This creative work takes on the perspective of a soldier in the New Order era, who in the effort to find his missing brother, encounters the harsh reality in Buru island that forces him to reconsider his naïve understanding of nationalism.
\end{abstract}

Keywords: Denial, Nationalism, Nation, Indonesia, Buru, Historical Fiction, History, Novel

\section{INTRODUCTION}

For this creative work, I will be writing a novel, because for me, conveying a story is easier through words alone. Essentially, novels allow people to imagine the story rather than to show it in a visual way (Calafiore, 2014). Also, through written words, I could better describe abstract concepts, such as emotions, thoughts, and fantasies (Prahl, 2019).

This creative thesis will discuss the issue of denial in relation to nationalism, specifically in Indonesia. Characteristically, nationalism is established on the idea of national loyalty, which exceeds any other individual or group interests (Kohn, 2019). Depending on the usage, this ideology can be positive or negative (Bertrand, 2004). In its positive usage, nationalism can work as a uniting force for the people by giving them a shared identity. Meanwhile, it manifests negatively when it divides and becomes harmful to society, such as in the form of xenophobia (Barone, 2017; UK Essay, 2018). Collier (as cited in Barone, 2017) stated that most people in the West see the conception of nationalism as negative, mainly for its accountability in causing World War I and II (Duara, 2018).

Indonesia too is no stranger to using nationalism for more negative ends, most notably during the New Order era. Under president Suharto's authoritarian rule, the Indonesian government used nationalism as a justification for suppressing and eliminating its opposition, leading to the death of over three million lives (Indonesia Investments, n.d.; Robinson 2018). However, what is interesting is that despite those past tragedies, most Indonesians still hold an excessively positive opinion on nationalism (Siahaan, 2018). According to Renaldi (2018), this is because nationalism is so fundamental to Indonesia's ideology that its people, most of whom are conservatives, still reject and deny any historical records that express an oppositional view.

Moreover, this hyper nationalist attitude exists just in the past but also in the present time. One example comes from 2012, when the government disallowed the official screening of the documentary, The Act of killing, in Indonesian theatres. The main reason for this 
disallowance was primarily because the Indonesian government bans films that discuss human right violations (Film Courage, 2013). This case highlights Indonesian government's, and in general, the Indonesian people's, unwillingness to discuss the human rights violation happening during the country's dark past and the associated denialist mentality that is still prevalent in Indonesia.

This mentality is further explained in a book titled, States of Denial, where sociologist Stanley Cohen defines denial as "the need to be innocent of a troubling recognition (as cited in Nadler, 2017, p. 27). On this, he explains that denial arises from an individual's "disturbing emotions aroused from external realities", such as guilt and anxiety (as cited in Jamieson, 2002). As such, a person would unconsciously fall into denial to block out unwanted knowledge that might cause him/her emotional distraught.

Furthermore, Cohen elaborates that the cause of denial comes not only from individual needs but also social ones (Nandler, 2017). He comments that denial in a social level is the result of maintaining a status quo "in which undesirable situation (event, condition or phenomenon such as domestic violence, racism, homophobia) is unrecognised, ignored or made to seem normal" (as cited in Jamieson, 2002).

Primarily concerned with human rights violations, Cohen identifies that in response to undesired circumstances or thoughts, a person will go through what he terms the spiral of denial (as cited in Nadler 2017; as cited in Shoham, 2015). In this process, there are three consecutive stages of denial (Nadler, 2017):

1. Literal or Factual Denial: denying facts or knowledge of the facts.

2. Interpretative Denial: acknowledging the raw facts but denying the suggested meanings or significance those facts represent.

3. Implicative Denial: acknowledging the facts and their intended meanings but denying the moral responsibility that comes from admitting those facts.

An example of this process is racial injustice. When a person hears a rumour about a person being severely abused due to racial differences, his/her initial response will be to deny that the incident ever happened, hence the first stage, literal denial. Then, once that person finds out from the news that it did happen, he/she will switch to the second stage, interpretive denial, which is taking the event not as a case of racial abuse but as a misunderstanding between both the parties involved. Lastly, when that person is confronted again by the truth, for example, through watching an independent investigation finding proof that the case is indeed an act of racial abuse, he/she will move to the third stage, implicative denial. In it, he/she will change his/her reasoning to not wanting to get involved in the event, including not condemning the racial abuse. Once that person has gone through the three stages, and the truth persists, he/she will have no other option but to accept it, hence breaking free from the spiral of denial.

In essence, Cohen's spiral of denial aims to identify the mechanism of denial in society and to help people acknowledge the sufferings of others and take action to alleviate those sufferings (Nadler, 2017). Elaborating on this, he introduced his concept of acknowledgement, which he stated as "the antidote to denial" (as cited in Nadler, 2017, p. 27). He explained that in understanding denial, one has to treat it like a paradox as it "allows for the strange possibility of simultaneously knowing and not knowing". This "not knowing" aspect of denial is the core issue of this paradox since the knowledge of what is being denied is already somehow known, and therefore, is not enough in solving the paradoxical problem (Nadler, 2017).

Cohen suggested that through acknowledgement, a person can admit that he is trying to deny a certain thing, which removes the "not-knowing" part of the denial paradox. Therefore, denial loses one of its two contradicting elements and in turn, loses its paradoxical nature. As 
Salim, et al.: This is My Country (?)

Exploring Denial in Relation to the Negative Aspects of Nationalism in Indonesia.

such, acknowledgment is Cohen's means to "transcend" the paradox of denial. Additionally, acknowledgement is divided into two types, which are (Jamieson, 2002):

1. Complete Acknowledgement: the complete acceptance of the denied facts, their intended meanings, and their consequences.

2. Spatial Acknowledgement: the condition where the denied facts, their intended meanings, and their consequences are partly accepted.

According to Cohen (as cited in Jamieson, 2002), the first form is generally more likely to happen to people who do not take part in the incident or situation that is being denied. Meanwhile, the second form is more likely to happen to people who are directly responsible towards the object of denial (Jamieson, 2002). In the case of this creative work, I will use the first form, Complete Acknowledgement, as it highlights the point of the story, which is for Indonesian readers to admit their long-harboured denial to nationalism with no compromise whatsoever.

In relation to nationalism itself, it can broadly be defined as "the central principle of political organization" (Heywood, 2017, p. 201). When elaborated further, however, it is also an ideological phenomenon characterised by its utter complexity and diverse contexts, concerning the issues of nation-building as well as the psychological impacts of its creed. As such, the scope of this ideology covers not only the major social and cultural aspects of a nation but also the more minor parts: the individual citizens and more specifically, their nationally constructed convictions (Heywood, 2017). These beliefs refer to the idea of national loyalty and devotion, which is a common feature of nationalism with massive social and political implications. This aspect of nationalism, the loyalty and devotion to one's nation, will be the focus of this creative thesis in its effort to reveal the potential of denial in nationalism.

There has been debates on whether nationalism is naturally positive or negative. In regard to this problem, Heywood (2017) argues that nationalism possesses "a schizophrenic political character" (p. 206), meaning that it can have positive or negative characteristics in given circumstances. In its positive forms, nationalism is responsible for building and rebuilding the political climate of European countries in the past two centuries and is arguably the most successful and compelling political creed in history (Heywood, 2017).

In its negative forms, however, nationalism can be misused to cause great adversities. George Orwell conceptualised this idea in his essay, Notes on Nationalism (1945), where he commented on nationalism's faulty, misleading, and easily misused capacity as a moral compass (as cited in Renovatio, 2017). Unlike other nationalist theorists, he is less concerned with nationalism's role in nation-building and governmental policies (the macro level) and more with its effects on individual mindsets and beliefs (the micro level). He further emphasises this point in his identification of the common human elements standing out most in many preexisting nationalistic models, like Communism and Political Catholicism (as cited in Renovatio, 2017). From these elements then, he developed "the principal characteristics of nationalist thought" (as cited in Williams, 2017), which include:

1. Obsession: a nationalist is obligatory to prove that his/her nation is superior to others, even to the point of extremity.

2. Instability: a nationalist's allegiance and devotion to a given cause is interchangeable for what matters to him/her is the passion of his/her belief, not the object of that belief.

3. Indifference to Reality: a nationalist's devotion alters his/her perception of reality to fit whatever he/she deems to be right and true. 
On the third characteristic, indifference to reality, Orwell claims that all nationalists are able to condemn other nations of a given crime while simultaneously not admitting to that same crime when done by his own country (as cited in Renovatio, 2017). This paradoxical nature of nationalistic thoughts has similar patterns to Staley Cohen's concept of denial, which is a state of "knowing" and "not knowing" at the same time (Nadler, 2017). Orwell further emphasises this correlation by stating, "facts are selected or suppressed in order to make a case; if need be, the necessary facts are simply invented or, contrariwise, erased" (as cited in Renovatio, 2017). Thus, according to him, since truth in a nationalist sense is alterable and discardable, "the most unmistakable fact can be impudently denied" (as cited in Williams, 2017). From these two statements, it can be concluded that denial is a notable, if not essential, feature of nationalistic thoughts, specifically in relation to the third characteristic, indifference to reality.

As such, I would like to address this concerning issue in this creative thesis, specifically on how unevaluated nationalist belief can blind a person from the suffering of others and in turn, cause that suffering to persist. Also, I wish to raise awareness to the Indonesian public about what happens to their country if the potential dangers of nationalism are denied.

Specifically, I want to direct this message to those who perceive nationalism as a totally positive characteristic that every good Indonesian should possess. Given how nationalism has been used to propel the dark interest of the New Order, it serves as a lesson that no one ideology should be perceived entirely positive.

Since the story will take place in 1970's Indonesia, I will be writing it under historical fiction, a genre that puts fictional stories within a historical setting (Switzer, 2017). In terms of value, this genre uses the past as a form of self-reflection with the purpose of highlighting recent issues (Tod, 2019). Historical fiction is popular among readers, garnering a second place in a 2015 survey with 33\% of all U.S. readers (Statista, 2016). In Indonesia's case, there is a lack of concrete data on the genre's overall popularity, but according to Rasyidin (2018), historical fiction novels make 4 out of 7 best Indonesian novels ever published, indicating a sizable market for this genre.

This creative work will talk about the story of Wahyudi, an Indonesian soldier serving during the New Order era, who wants nothing more than to find his missing brother, Wira. His journey leads him to Buru Island, where he will face many terrible truths that challenge his naive, unquestioned belief in nationalism. This story will focus on Wahyudi's struggle in choosing between what is dear to him and his stubborn clinging to his nationalist ideals. At the cost of many lives, he will eventually acknowledge the truth of his denial and give up his nationalism.

\section{OUTLINE OF CREATIVE WORK}

\subsubsection{Theme}

My topic, denial in nationalism, covers many aspects of my creative thesis, but most important of all, it serves as the main issue I want to address in my creative work. To be precise, through this story, I want to point out that no ideology, including nationalism, is ever completely positive or completely negative. Everything comes with both positive and negative elements and admitting only to the former will blind one from seeing the destructive potential of the later. Therefore, it is advisable that people assess things in a critical way regardless of how positive society perceives them. 
Salim, et al.: This is My Country (?)

Exploring Denial in Relation to the Negative Aspects of Nationalism in Indonesia.

\subsubsection{Plot}

In 1970, Wahyudi, a soldier, went home to his village in Pasuruan to visit his grandmother's grave. During his stay, he stumbled upon a letter from his long-lost brother, Wira. Trying to find Wira, Wahyudi traced back the letter to Surabaya, where he and his friend, Saleh, learnt that Wira was in Buru island. Due to a lucky coincidence, they are able to travel there through a voluntary military transfer.

Weeks after, in Buru Island, Golonel Gatot assigned Wahyudi and Saleh to watch the labour camp in unit IX Arjuna, where they first encountered the prisoners. Despite the harsh treatment towards the prisoners, Wahyudi disregards their sufferings out of blind spite. In a lucky encounter, Wahyudi finds his brother, Wira, working under a priest named Mother Grace. Wira promised to return home with Wahyudi once he finished his job there. However, it turned out later that his beloved superior, Setyo, was responsible for smuggling prisoners out of the camps. Gatot executed Setyo for treason, which made Wahyudi question his pro-nationalistic belief, but Saleh convinced him that Setyo deserves his brutal punishment.

Still sad over Setyo's death, Wahyudi visited Wira, but he happened to run across a runaway prisoner whom Setyo smuggled out, named Rahamdi. After a brief scuffle, Wahyudi learnt that Mother Grace and Wira were the ones behind Setyo's incident. Not wanting Wira to get captured, Wahyudi convinced Rahamdi to commit suicide to cover up the truth, which caused Wira to despise his brother. Unfortunately, Gatot found out about the conspiracy and with his men, execute Mother Grace and the villagers who sheltered her. Before the general kills Wira, however, Wahyudi convinced him that Wira would be a useful intelligence for the military. However, despite Wahyudi's attempt to save his brother, Wira refused.

On the day of his execution, however, Wira confronted Gatot about freedom which caused a riot between the prisoners and the soldiers. With Saleh's help, Wahyudi and Wira escaped, but Gatot caught up to them, causing Saleh to sacrifice his life. After a failed negotiation, Gatot shot Wira down, prompting Wahyudi to kill him. Wahyudi lamented on Wira's death as the reinforcing soldiers subdued him. At that moment, Wahyudi finally acknowledged his denial and accepted the terrible truth of Wira's death and his responsibility in it.

\subsubsection{Characters}

\section{Main Characters}

- Wahyudi (22 years old)

Wahyudi is a young man with a very stubborn attitude. Growing up in the countryside with his brother and grandmother, he has a simple view of life and often jumps into conclusion and blindly follows whatever others say. He's also a determined person who will achieve his goal once he decides on something to the point of offending others. As such, he has few friends, but he takes great care of those who cherish him. This is the case with his brother, Wira, whom he's been looking for ever since his disappearance. He would do anything to find his brother, even at the cost of others' lives.

- Wira (25 years old)

Wira is Wahyudi's older brother. Like his brother, he is very stubborn with his ideal, in this case, his sense of justice and egality. Unlike his brother, however, he is gentle, polite, and 
understanding towards others. He also loves books, which led him to pursue education in the city, leaving his small family behind. After witnessing the communist massacre of 1965 firsthand, however, he was determined to dedicate his life to fight against social oppression and injustice. With that intention, he joined Mother Grace as a volunteer to free prisoners from the brutal clutch of the New Order regime.

\section{Supporting Characters}

- $\quad$ Saleh (22 years old)

Saleh is Wahyudi's best friend. Born into a rich family, he is naturally a smug yet cheerful person. Though he is very lax most of the time, he cares a lot about people dear to him and is willing to do anything to protect them.

- $\quad$ Setyo (64 years old)

Setyo is a veteran soldier who has served his country for 30 years. He is admired by his subordinates and juniors as very warm and friendly. He likes to joke around and give useful life advices, almost like a father figure. Behind his approachable figure, he is tough and wise person, who learnt to appreciate human lives unconditionally. As such, he secretly despises how the New Order regime treats its oppressed citizens and thus, supported Mother Grace's secret operation to rescue prisoners out of Buru island.

- $\quad$ Mother Grace (36 years old)

Mother Grace is a priest who manages a chapel in Buru Island. She is a strong-willed individual. She is a Chinese immigrant who finds her calling as a priest and devotes her life to protecting marginalised people. Her aspiration brought her to Buru island, where she headed a secret operation to free the prisoners in the labour camps and give them a new life abroad.

- $\quad$ Gatot (41 years old)

Colonel Gatot is the leader of the Buru Island labour operation. He is a stern and loyal believer in the government, executing his orders without questions. Known as a very strict and ruthless leader, he punishes offenders with brutality, without regards to their humanity. Furthermore, he has a particular hatred for communists and traitors whom he sees as "enemies of the state", and in turn, he treats all communists and prisoners inhumanely.

- $\quad$ Rahamdi (39 years old)

Rahamdi is a prisoner in camp unit IX, adored by both his peers and his captors for being a cheerful fellow. Despite his fun personality, however, he hides a scar of his oppression and secretly wants his sad life to end.

\subsubsection{Conflict}

The conflict in this creative work manifests in two forms, internal and external. In terms of internal conflict, the story is portraying a Man vs Self scenario, which depicts a character's struggle against himself or herself (Masterclass, 2019). In the case of external conflict, the story also discusses Man vs man conflicts, a case where the protagonist faces an opponent in either a literal or metaphorical battle (Masterclass, 2019). The internal conflict is more dominant because this creative work focuses more on exploring my protagonist's inner dilemma. 
Salim, et al.: This is My Country (?)

Exploring Denial in Relation to the Negative Aspects of Nationalism in Indonesia.

\subsubsection{Setting}

Set in 1970's Indonesia, this story takes place in three major settings: Surabaya city, Wahyudi's fictional village in Pasuruan, and Buru island. Some notable locations in the story are Wahyudi's fictional village in Pasuruan, Saleh's apartment room in Surabaya, and Camp unit IX Arjuna in Buru island.

\section{CONCLUSION}

As I have stated in the beginning of this creative thesis, I have always dreamt of writing a full-length novel, and I finally manage to do so in the form of this creative work. In this wonderful experience, there are a few lessons I picked up along the way.

First, I learnt that research is a troublesome yet useful guide to writing a good story. Before doing this creative thesis, I never knew that a creative work, novel or other literary forms, has to have a theoretical foundation. As such, I struggle a lot in the research process, mostly due to the lack of resources related to my topic. It is the most difficult and tiring part in constructing this thesis. However, the theories and concepts also provide a good structure for the story's plot. In my case, Stanley Cohen's spiral of denial shaped the skeleton of my story, making it easier for me to write it. In addition, the countless hours of researching have made it easier for me to find more resources and information. Before, I avoided using resources with thicker contents, like a book or a journal, but now, I can skim through them comfortably.

Second, I learnt that an idea when written can change a lot from the original conception. This is probably the biggest challenge in writing this creative work. In many cases, I needed to change some details or plotlines so the story can work better. The biggest problem with that is the changing length of certain storylines. I tend to overwrite parts that originally take just a few paragraphs while underwriting the more major ones. As such, the editing process takes a very long time.

Last, I learnt that physical and mental health are essential in my writing process. In these past two semesters, there were a few moments where I exerted myself and as a result, acutely burnt out. On one occasion, I was so worried about my work that I got severely sick and awfully depressed. The struggle persisted for a long stretch of time, but fortunately for me, some of my good friends helped me go through those dark times. Since then, I have tried to not overwork myself and manage to have enough rest while enduring a tough schedule. Though this may not be an academic concern, I believe that taking great care of oneself is a major factor in completing this difficult task, and it is indeed the biggest takeaway from my experience working on this creative work.

\section{REFERENCES}

Barone, M. (2017). Nationalism can be a force of the good. Washington Examiner. Retrieved from https://www.washingtonexaminer.com/nationalism-can-be-a-force-for-the-good

Bertrand, J. (2004). Nationalism and ethnic conflict in Indonesia. Cambridge, United Kingdom: Cambridge University Press.

Calafiore, S. (2014). The novel or the film? Retrieved from https://the-artifice.com/the-novelor-the-film/ 
Duara, P. (2018). Development and the crisis of global nationalism. Retrieved from https://www.brookings.edu/blog/future-development/2018/10/04/development-and-thecrisis-of-global-nationalism/

Film Courage. (2013). How we avoided THE ACT OF KILLING being banned In Indonesia by Joshua Oppenheimer [Video file]. Retrieved from https://www.youtube.com/watch?v=_atw_Lld8bI

Heywood, A. (2017). Political ideologies: An introduction (6th ed.). [e-book]. Retrieved from https://books.google.co.id/books?hl=en\&lr=\&id=Sy8hDgAAQBAJ\&oi=fnd\&pg=PR8\&d $\mathrm{q}=$ political+ideologies+an+introduction \&ots $=\mathrm{G} 3$ YOmBakyT \&sig $=\mathrm{kVmEjNiGxKRZ6 \textrm {tU }}$ $\mathrm{nBcuhR}$ thqP6U\&redir_esc $=\mathrm{y} \# \mathrm{v}=$ onepage $\& \mathrm{q}=$ political $\% 20$ ideologies $\% 20 \mathrm{an} \% 20$ introduct ion $\& \mathrm{f}=\mathrm{false}$

Indonesia Investment. (n.d.). Suharto's New Order: Development of Indonesian under authoritarian rule. Retrieved from https://www.indonesiainvestments.com/culture/politics/suharto-new-order/item180

Jamieson, R. (2002). Denial, acknowledgement and reconciliation. What kind of truth and reconciliation model is appropriate for the former Yugoslavia? Conference Proceedings of Victimology Society of Serbia and Friedrich Ebert Stiftung, Belgrade, Serbia. Retrieved from https://www.researchgate.net/publication/47748789_Denial_acknowledgement_and_reco nciliation

Kine, P. (2014). Indonesia's act of denial. Retrieved from https://www.hrw.org/news/2014/03/03/indonesias-act-denial

Kohn, H. (2019). Nationalism. Retrieved from https://www.britannica.com/topic/nationalism

Masterclass. (2019). What is historical fiction? Definition of the historical fiction genre and tips for writing your historical novel. Retrieved from

https://www.masterclass.com/articles/what-is-historical-fiction-definition-of-thehistorical-fiction-genre-and-tips-for-writing-your-historical-novel\#what-is-historicalfiction

Nadler, C. (2017). Denial: A sociological theory (Doctoral dissertation, City University of New York, New York, United States of America). Retrieved from https://academicworks.cuny.edu/gc_etds/2126/

Prahl, A. (2019). What is a novel? definition and characteristics. Retrieved from https://www.thoughtco.com/what-is-a-novel-4685632

Rasyidin, S. (2018). 7 novel Indonesia terpopuler sepanjang sejarah, karya Hamka paling dinikmati. Tribbune.com. Retrieved from https://palembang.tribunnews.com/2018/08/14/7-novel-indonesia-terpopuler-sepanjangsejarah-karya-hamka-paling-diminati?page $=4$

Renaldi, A. (2018). The New Order ended 20 years ago, but Indonesian students still aren't taught the full story. Retrieved from https://www.vice.com/en_asia/article/j5kme3/thenew-order-ended-20-years-ago-but-indonesian-students-still-arent-taught-the-full-story

Renovatio. (2017). Notes on nationalism. Retrieved from https://renovatio.zaytuna.edu/article/notes-on-nationalism

Robinson, G. B. (2018). The killing season: A history of the Indonesian massacres, 1965-66. New Jersey, United States of America: Princeton University Press.

Shoham, E. (2015). Victim rhetoric among sex offenders: A case study of the former Israeli president. Journal of Politics and Law, 8(1). doi: 10.5539/jpl.v8n1p26

Siahaan, J. T. H. (2014). Membudidayakan nasionalisme dan persatuan. Kompas.com. Retrieved from https://nasional.kompas.com/read/2018/11/29/05000091/membudidayakan-nasionalismedan-persatuan?page $=$ all

Statista. (2016). What type of books have you read in the past year? Retrieved from https://www.statista.com/statistics/201404/types-of-books-that-american-adults-read/ 
Salim, et al.: This is My Country (?)

Exploring Denial in Relation to the Negative Aspects of Nationalism in Indonesia.

Switzer, C. (2017). Characteristics of a historical fiction novel. Retrieved from https://penandthepad.com/characteristics-historical-fiction-novel-6621726.html

Tod, M. K. (2019). History as a mirror of our present by Alice Poon. Retrieved from https://awriterofhistory.com/2019/11/05/history-as-a-mirror-of-our-present-by-alicepoon/

UK Essays. (2018). What is the concept of nationalism? Retrieved from https://www.ukessays.com/essays/sociology/what-is-the-concept-of-nationalismsociology-essay.php

Williams, K. (2017). What George Orwell wrote about the dangers of nationalism. Retrieved from https://lithub.com/what-george-orwell-wrote-about-the-dangers-of-nationalism/ 